\title{
Parafuscosporella garethii sp. nov. (Fuscosporellales) from a rivulet in a community-based northern forest, in Thailand
}

\author{
Boonyuen $\mathbf{N}^{1 *}$, Chuaseeharonnachai $\mathbf{C}^{\mathbf{1}}$, Suetrong $\mathbf{S}^{\mathbf{1}}$, Sujinda $\mathbf{S}^{\mathbf{1}}$ and \\ Somrithipol $\mathbf{S}^{1}$
}

'BIOTEC, National Science and Technology Development Agency (NSTDA), 113 Thailand Science Park, Thanon Phahonyothin, Tambon Khlong Nueng, Amphoe Khlong Luang, Pathum Thani 12120, Thailand

Boonyuen $N^{1}$, Chuaseeharonnachai $C^{1}$, Suetrong $S^{1}$, Sujinda $S^{1}$ and Somrithipol $S^{1} .2016-$ Parafuscosporella garethii sp. nov. (Fuscosporellales) from a community northern forest, in Thailand. Mycosphere 7 (9), 1265-1272, Doi 10.5943/mycosphere/7/9/2

\begin{abstract}
Parafuscosporella garethii, a new freshwater taxon, is described and illustrated from submerged decaying twigs in a Thai community forest located in Chiang Mai Province. The species is recognized as the third species in the genus, and markedly differs from those previously accepted in the genus by its conidial size and shape and having two forms of conidiogenous cells. Phylogenetic analysis based on combined LSU, SSU and RPB2 sequence data place $P$. garethii in Fuscosporellales, Hypocreomycetidae, Sordariomycetes. The novel taxon is compared with morphologically and phylogenetically similar species in the genus and a taxonomic comparison to accepted Parafuscosporella species is also provided.
\end{abstract}

Key words - E.B. Gareth Jones - freshwater fungi - Fuscosporellaceae - phylogeny - taxonomy

\section{Introduction}

Parafuscosporella (Fuscosporellaceae, Fuscosporellales, Hypocreomycetidae and Sordariomycetes) was introduced by Yang et al. (2016) with P. moniliformis and P. mucosa, as the type and second species in the genus, respectively. These two species were isolated from unidentified submerged twigs in a freshwater stream of Prachuap Khiri Khan Province, Thailand. The genus is characterized by partly immersed, partly superficial, septate, hyaline to pale brown mycelium; semi-macronematous, mononematous, branched, monoblastic, globose to subglobose, smooth-walled, hyaline conidiophores; and conidia that are ellipsoidal to broadly obpyriform, 1septate, with a septum near the base, sometimes with a protuberance, and a smooth, dark brown to black, pale brown at basal cell (Yang et al. 2016).

During a mycological survey of microfungi at a small stream located in a community forest in Chiang Mai Province, northern Thailand, P. garethii was found on submerged decaying twigs and is described as a new species here. The new taxon differs from other Parafuscosporella species in having two conidiophore types and in conidial shape and size. Phylogenetic evidence place the taxon in Fuscosporellales with strong bootstrap support. Parafuscosporella garethii is therefore introduced as a third species in the genus and is a novel freshwater taxon from Thailand. 


\section{Materials \& Methods}

\section{Collection, isolation, culture, SEM and morphological analysis}

Naturally submerged twigs were randomly collected at Ban Hua Thung, Chiang Dao District in Chiang Mai Province, Thailand $\left(19^{\circ} 25^{\prime} 14^{\prime \prime} \mathrm{N}, 98^{\circ} 58^{\prime} 17^{\prime \prime} \mathrm{E}\right)$, at an altitude of about 446 above sea level in August 2015. They were placed in plastic Zip lock bags and then brought to the laboratory at the National Center for Genetic Engineering and Biotechnology (BIOTEC). The woody samples were incubated in plastic containers with sterile tissue paper soaked with sterile distilled water at room temperature $\left(\sim 20-25^{\circ} \mathrm{C}\right)$ for $7-14$ days and examined under a stereo microscope (OLYMPUS SZ61) for the presence of microfungi as previously outlined by Chuaseeharonnachai et al. (2016). Germinated spores were transferred to potato dextrose agar plates (PDA, Santa Maria, California). Culture studies and morphological characteristics i.e. mycelium, colour, shape, texture, conidiomata, conidiogenous cell, conidiophores and conidia were determined using a compound microscope (OLYMPUS CX31). Measurements were taken from fresh material mounted in water and micrographs were obtained with an Olympus microscope equipped with differential interference contrast (OLYMPUS DP70). Small pieces of the natural substrate containing fungal fruiting body and conidia were prefixed in $5 \%$ glutaraldehyde in $0.1 \mathrm{M}$ sodium phosphate buffer at $4^{\circ} \mathrm{C}$ for $12 \mathrm{~h}$, dehydrated in ethanol series and finally substituted with isoamyl acetate. After critical point drying, the specimens were coated with $1 \%$ osmium tetroxide for $2 \mathrm{~h}$ and then gold (Eiko Engineer IB-2) Finally, it was observed with a JSM-6060 (JEOL, JSM-5600 LV, Japan) operated at $10 \mathrm{kV}$. The type specimens are deposited at the BIOTEC Bangkok Herbarium (BBH, Thailand) as BBH40839 (BBH, holotype) and BBH40840 (BBH, paratype). Pure cultures are maintained in Thailand Bioresource Research Center (TBRC) as TBRC6543 \& TBRC6544 and kept at BIOTEC Culture Collection (BCC) as BCC 79986 \& BCC79987. Index Fungorum and Faces of Fungi numbers are registered as outlined in Index Fungorum (2016) and Jayasiri et al. (2015).

\section{DNA extraction, PCR, sequencing, alignment and phylogenetic analysis}

Genomic DNA was directly extracted from mycelium on PDA using a CTAB method (O'Donnell et al. 1997). The small subunit ribosomal RNA (SSU) were amplified with primers NS1 and NS6 (White et al. 1990) and the large subunit ribosomal RNA (LSU) were amplified with JS1 and JS8 (Sakayaroj 2005), while primers 5F2 and 7cR (Liu et al. 1999) were used to amplify part of the RNA polymerase II second largest subunit (RPB2). The PCR mixtures and PCR amplification conditions using a DNA Engine DYAD ALD T100 ${ }^{\mathrm{TM}}$ Thermal Cycler (BIO-RAD, USA) were performed as described by Sakayaroj (2005). PCR products were sequenced by Macrogen Inc. (South Korea) using the same primers as for amplification. The newly generated sequences (BBH40839 and BBH40839) with their original codes were deposited in GenBank as KX958428, KX958429 for SSU; KX958430, KX958431 for LSU and KX958432, KX958433 for RPB2, respectively. The consensus sequences for each gene and representative taxa (in-group) downloaded from National Center for Biotechnology Information; NCBI (2016) with their original codes are shown in the tree (Fig. 1). Incomplete portions at the ends of the sequences were excluded from the analyses. The single gene alignments of SSU, LSU and RPB2 were concatenated into a combined dataset and were aligned using Bioedit (Hall 2004) and the alignment in TreeBASE was registered as submission ID: S19635 (www.treebase.org). Maximum parsimony analysis (MP) was performed with PAUP (Phylogenetic Analysis Using Parsimony) v. 4.0b10 (Swofford 2002). Ambiguously aligned regions were excluded from dataset and gaps in SSU, LSU and RPB2 regions were treated as missing data. Trees were inferred using the heuristic search option with TBR branch swapping and 1000 random sequence additions. Branches of zero length were collapsed and all equally most parsimonious trees were saved. Tree length (TL), consistency index (CI), retention index (RI), rescaled consistency index (RC), and homoplasy index (HI) were calculated. Trees were visualized in TreeView v. 1.6.6 (Page 1996). Bootstrapping for maximum parsimony (MP) defined as bootstrap values (BSMP), Bayesian posterior probabilities (BYPP), and maximum likelihood (BSML) were performed as following method of Boonyuen et al. (2011). 


\section{Results}

\section{Phylogenetic analyses}

The combined LSU, SSU and RPB2 sequence data were used to resolve the species placement of $P$. garethii (strains TBRC 6543, TBRC 6544). Phylogenetic trees obtained from MP, ML, and Bayesian analyses yielded trees with similar overall topology at the subclass, order and family levels (data not shown) and this topology is in agreement with previous papers based on ML analysis using RAxML (Maharachchikumbura et al. 2015, 2016, Réblová et al. 2016). One of the most six parsimonious trees was chosen and is shown in Fig. 1. The alignment datasets included 63 taxa of which Phacidium lacerum and Bulgaria inquinans (Leotiomycetes) were used as the outgroup taxa. Of the 3314 characters, 1607 were constant, 315 and 1392 were variable parsimony uninformative characters and parsimony-informative characters, respectively. Differences between the most six parsimonious trees include minor swapping of positions between some taxa i.e. Ascotaiwania lignicola, A. limnetica, A. mitriformis and Triadelphia uniseptata in Savoryellales and Etheirophora blepharospora and Swampomyces armeniacus in Etheirophoraceae. The best phylogenetic tree is presented in Fig. $1(\mathrm{TL}=8243, \mathrm{CI}=0.357, \mathrm{RI}=0.591, \mathrm{RC}=0.211, \mathrm{HI}=$ 0.643 ) and clearly demonstrates that $P$. garethii (TBRC 6543, TBRC 6544) grouped in the order Fuscosporellales. The phylogenetic data also shows that $P$. garethii is a sister taxon to Fuscosporella pyriformis MFLUCC 16-0570, Pituitospora pseudoseptata MFLUCC 15-0618, Bactrodesmiastrum obovatum FMR 6482, B. pyriforme FMR 11931, and Pseudoascotaiwania persoonii A57-14C (Hernández-Restrepo et al. 2015, Yang et al. 2016).

\section{Taxonomy}

Parafuscosporella garethii Boonyuen, Chuaseehar. \& Somrith., sp. nov. Index Fungorum Number: IF552573

Facesoffungi number: FoF02723

Etymology - Named after Professor E.B. Gareth Jones in recognition and celebration of his $80^{\text {th }}$ birthday in January 2017 and his contributions to tremendous changes in Asian fungal classification, identification and nomenclature, particularly on freshwater fungi in Thailand.

Saprobic on submerged wood. Colonies on natural substrata, granular, black. Mycelium mostly superficial and partly immersed in the substrata, composed of branched, septate, smoothwalled, hyaline, 1.25-2.5 $\mu \mathrm{m}$ thick hypha. Sexual morph - Undetermined. Asexual morph coelomycetous, sporidochial - Conidiomata sporodochial, scattered, spherical to cushion-shaped, with jelly-like cover, gelatinous, $0.5-0.8 \times 0.5-0.7 \mathrm{~mm}$ diameter. Conidiophores micronematous, mononematous, compact, erect or flexuous, branched, septate, smooth-walled, hyaline, cylindrical or mostly moniliform with globose to subglobose or ellipsoidal to clavate cells, $10-15 \times 7.5-8 \mu \mathrm{m}$, connected centrically, up to $62.5 \mu \mathrm{m}$ long. Conidiogenous cells holoblastic, monoblastic, integrate or discrete, smooth-walled, hyaline, cylindrical, 1.25-2.5 $\mu \mathrm{m}$ wide or globose to subglobose, 8$12.5 \mu \mathrm{m}$ wide, or ellipsoidal, 10-15 × 7.5-8 $\mu \mathrm{m}$. Conidial secession rhexolytic. Conidia solitary, acrogenous, smooth-walled, obpyramidal, coronate at the apex, $2(-3)$ celled with transverse septum near the base, distal cell black, basal cell (s) light brown, (37.5-) 40-47.5 $\times(25-)$ 27.5-42.5 $\mu \mathrm{m}$, 20-32.5 $\mu \mathrm{m}$ thick $(\overline{\mathrm{x}}=43.1 \times 35.1 \times 24.3 \mu \mathrm{m}, \mathrm{n}=50)$, with a distinct basal frill $2-5 \mu \mathrm{m}$ long. Conical projections arising from the tip of conidia, 4-9-conical, 5-7.5 $\times 5 \mu \mathrm{m}$.

Culture characteristics - Conidia germinating on PDA within 48 hours. Colonies on PDA slow-growing, attaining $12.6-15 \mathrm{~mm}$ diameter in 40 days at $20-25^{\circ} \mathrm{C}$, floccose, rounded, greenishgrey at first, becoming grey to dark grey when aged (27F2/27F1); reverse sallow, yellowish-grey to dark grey with age (colours: 2B2/2F1; Kornerup \& Wanscher JH 1963), mycelium partly immersed and partly superficial, sporulating with prolonged incubation time. Conidiophores reduced to conidiogenous cells. Conidiogenous cells holoblastic, monoblastic, integrate, cylindrical, smooth-walled, hyaline, 2-2.5 $\mu \mathrm{m}$ wide. Conidial secession rhexolytic. Conidia acrogenous, solitary, smooth-walled, obovoid to pyriform, 2(-3)-celled with transverse septum near the base, 22.5-30 $\times 15-25 \mu \mathrm{m}(\overline{\mathrm{x}}=25.3 \times 21.3 \mu \mathrm{m}, \mathrm{n}=$ 30), upper cell(s) brown to dark brown, basal cell light brown; Chlamydospores absent. 


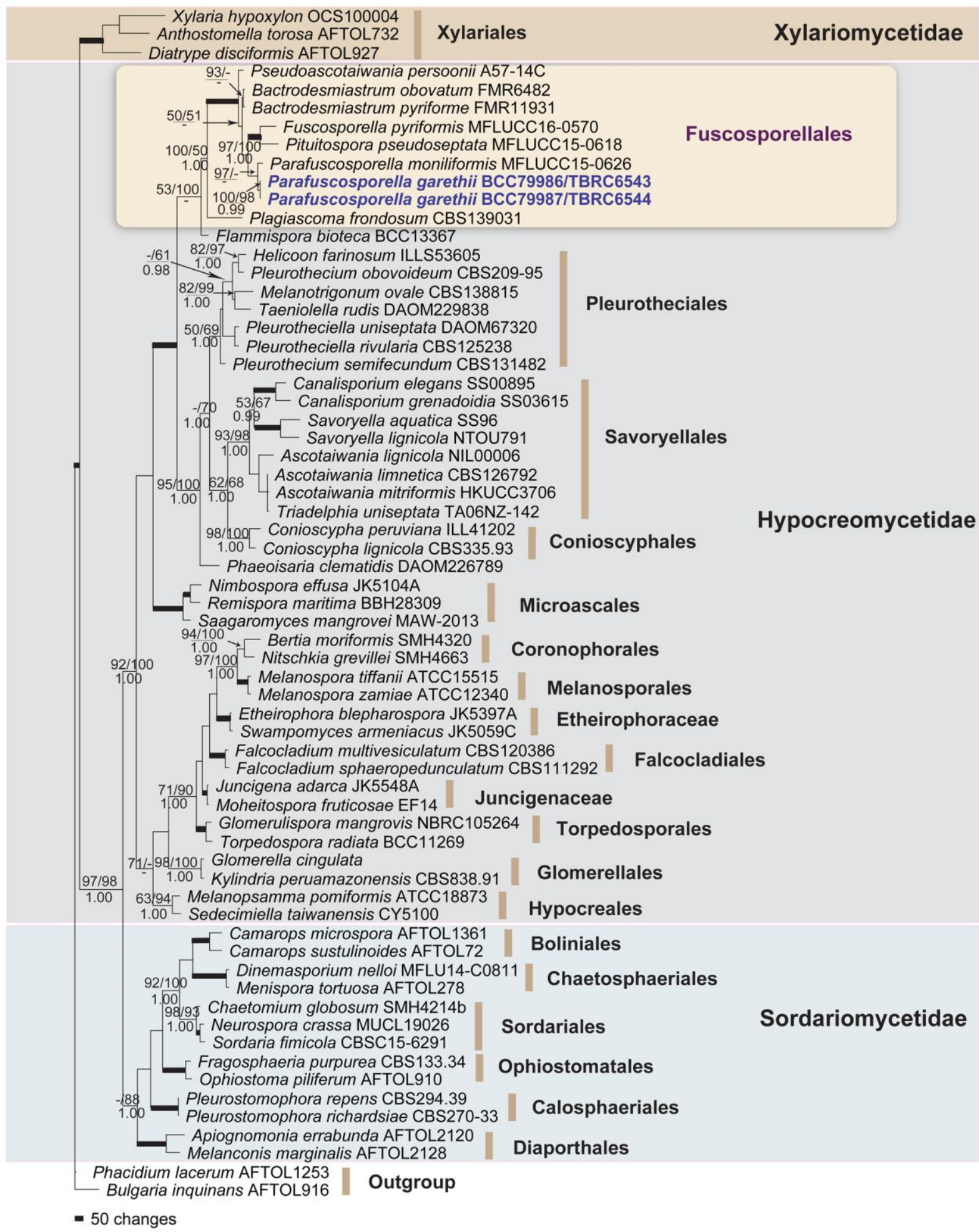

Fig. 1 - One of most parsimonious trees generated from MP analysis of combined LSU, SSU and RPB2 sequence data. Parsimony bootstrap support values (BSMP; at the top left) and maximum likelihood bootstrap (BSML; at the top right) $\geq 50 \%$ are indicated on the nodes; while the numbers below the branches $\geq 95 \%$ are the Bayesian posterior probabilities (BYPP; at the below). Strain numbers are given after the taxon names. 

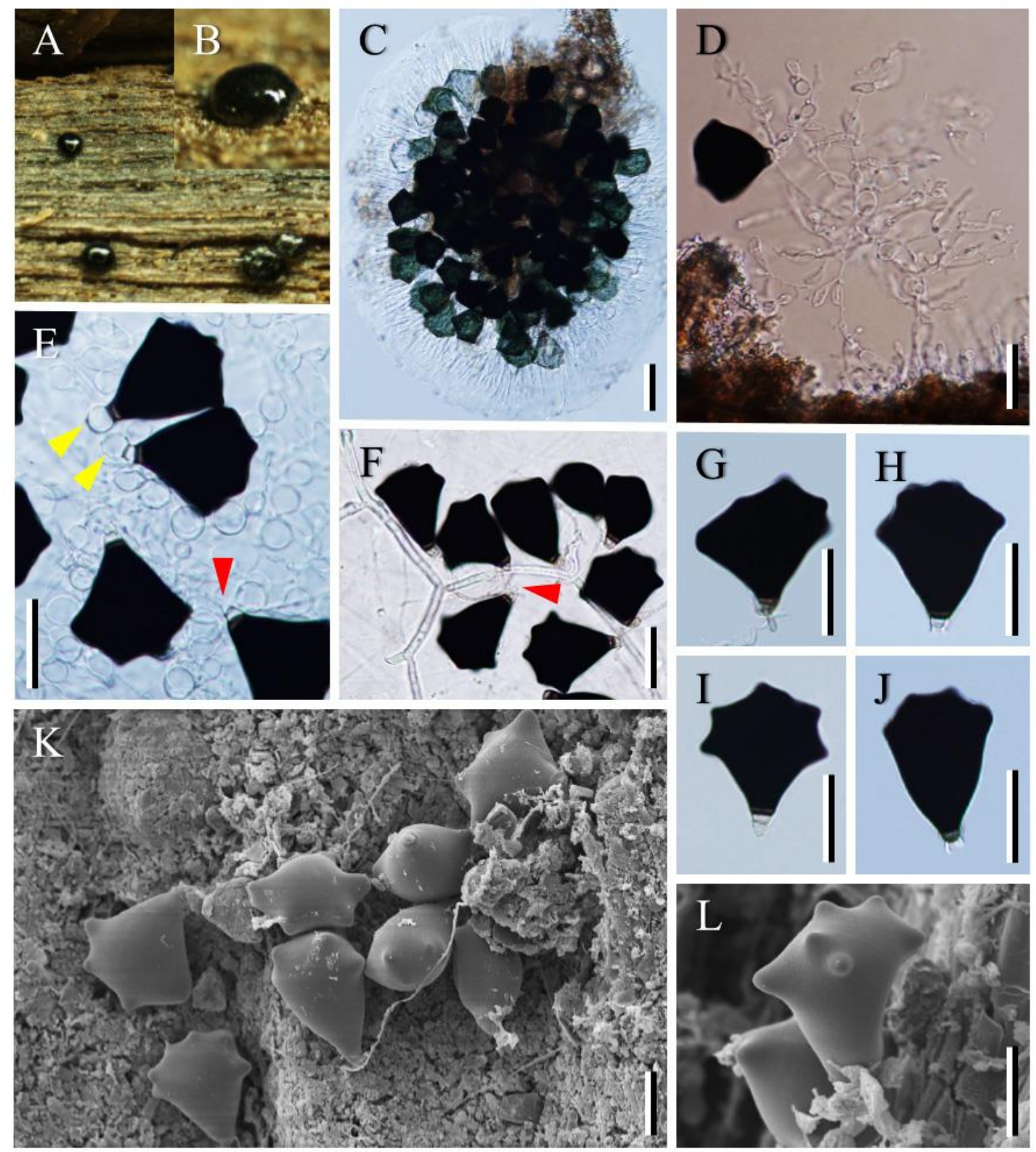

\section{M}
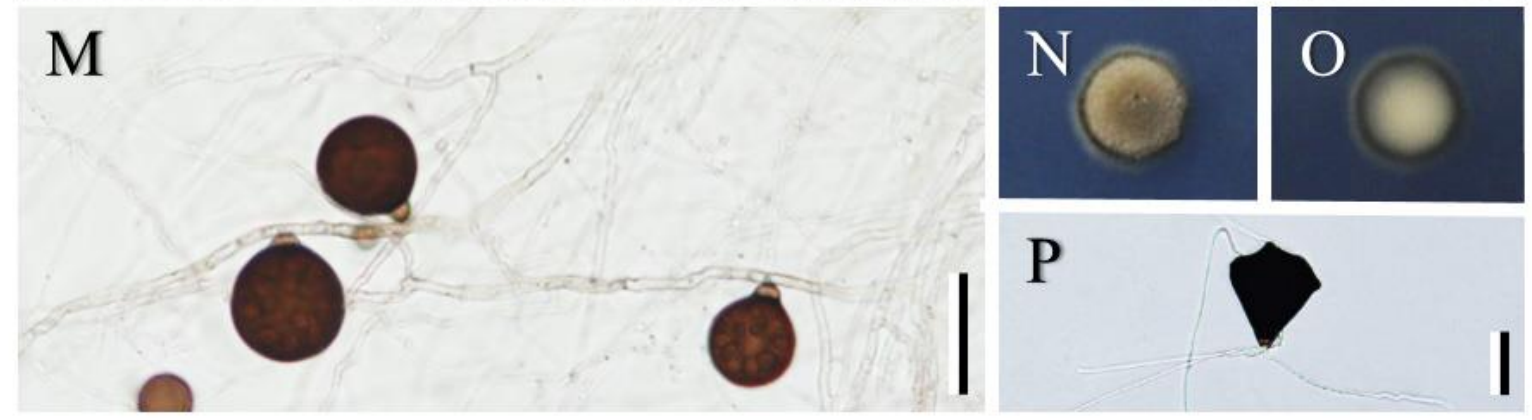

Fig. 2 - Parafuscosporella garethii (BBH 40839). A-B Sporodochia on submerged wood. C Squash mount of a sporodochium. D Conidiophores with conidiogenous cells and conidia. E-F Conidia with conidiogenous cells using yellow and red arrows showing conidia with globose to subglobose conidiogenous cells, and cylindrical conidiogenous cells, respectively. G-J Detached mature conidia. K-L Conidiophores, conidiogenous cells and conidia (SEM). M Sporulating conidia and its hyphae on PDA. N-O Obverse and reverse views of colony after incubated at $25^{\circ} \mathrm{C}$ on PDA for 30 days. P Germinating conidium on PDA. - Bars $C=50 \mu \mathrm{m}$; D-M, P $=25 \mu \mathrm{m}$. 
Table 1 Comparison characteristics of Parafuscosporella species.

\begin{tabular}{|c|c|c|c|c|c|c|c|}
\hline \multirow[t]{2}{*}{ Species } & \multirow[t]{2}{*}{ Conidiomata } & \multirow[t]{2}{*}{ Conidiophore } & \multirow[t]{2}{*}{ Conidiogenous cell } & \multicolumn{2}{|c|}{ Conidium } & \multirow[t]{2}{*}{ Substratum/Habitat } & \multirow[t]{2}{*}{ Reference } \\
\hline & & & & Size & Shape and colour & & \\
\hline P. moniliformis & $\begin{array}{l}\text { Sporodochial without } \\
\text { jelly-like cover }\end{array}$ & $\begin{array}{l}\text { Mostly moniliform, } \\
13-60 \times 3.5-6 \mu \mathrm{m} \text {; } \\
\text { each moniliform cell } \\
13.5-23 \times 3.5-6 \mu \mathrm{m}\end{array}$ & $\begin{array}{l}\text { Globose, subglobose, } \\
\text { ellipsoidal or clavate, } \\
5.5-36 \times 5-21 \mu \mathrm{m}\end{array}$ & $28-37 \times 14-21 \mu \mathrm{m}$ & $\begin{array}{l}\text { Ellipsoidal to broadly } \\
\text { obpyriform, unisepate, } \\
\text { dark brown to black }\end{array}$ & $\begin{array}{l}\text { Decaying submerged } \\
\text { wood, Prachuap Khiri } \\
\text { Khan Province, } \\
\text { Thailand }\end{array}$ & Yang et al. (2016) \\
\hline P. тисова & $\begin{array}{l}\text { Sporodochial with jelly- } \\
\text { like cover }\end{array}$ & $\begin{array}{l}\text { Cylindrical, } 12.5-37 \times \\
4-9 \mu \mathrm{m}\end{array}$ & $\begin{array}{l}\text { Globose, subglobose, } \\
\text { ellipsoidal or clavate, } \\
7-17 \times 4-12 \mu \mathrm{m}\end{array}$ & $26.5-36 \times 12-26 \mu \mathrm{m}$ & $\begin{array}{l}\text { Obovoid to } \\
\text { obpyriform, unisepate, } \\
\text { brown to dark brown }\end{array}$ & $\begin{array}{l}\text { Decaying submerged } \\
\text { wood, Prachuap Khiri } \\
\text { Khan Province, } \\
\text { Thailand }\end{array}$ & Yang et al. (2016) \\
\hline P. garethii & $\begin{array}{l}\text { Sporodochial with jelly- } \\
\text { like cover, } 0.5-0.8 \times \\
0.5-0.7 \mathrm{~mm} \text { diam. }\end{array}$ & $\begin{array}{l}\text { Cylindrical, } 1.25-2.5 \\
\mu \mathrm{m} \text { wide, mostly } \\
\text { moniliform; each } \\
\text { moniliform cell } 10-15 \\
\times 7.5-8 \mu \mathrm{m} \text {, and up to } \\
62.5 \mu \mathrm{m} \text { long }\end{array}$ & $\begin{array}{l}\text { Cylindrical, mostly } \\
\text { globose to } \\
\text { subglobose or } \\
\text { ellipsoidal, } 2-2.5 \mu \mathrm{m} \\
\text { wide or } 10-15 \times 7.5- \\
8 \mu \mathrm{m}\end{array}$ & $\begin{array}{l}37.5-47.5 \times 25-42.5 \\
\mu \mathrm{m}, 20-32.5 \mu \mathrm{m} \\
\text { thick }\end{array}$ & $\begin{array}{l}\text { Obpyramidal, } \\
\text { coronate at the apex } \\
\text { with } 4-9 \text { conical } \\
\text { projections }(5-7.5 \times \\
2.5 \mu \mathrm{m}), 1-2 \\
\text { transversally septa, } \\
\text { black }\end{array}$ & $\begin{array}{l}\text { Unidentified } \\
\text { submerged twigs, } \\
\text { Chiang Mai Province, } \\
\text { Thailand }\end{array}$ & This paper \\
\hline
\end{tabular}

Material examined - Thailand, Chiang Mai Province, Chiang Dao District, a small stream at Ban Hua Thung community forest, $19^{\circ} 25^{\prime} 14^{\prime \prime} \mathrm{N}$, 98 58'17"E, on unidentified decaying submerged wood, August 2015, S. Sommai, FF00725.01 (BBH 40839, holotype) - ex-type living culture BCC79986 (TBRC 6543); Thailand, Chiang Mai Province, Chiang Dao District, a stream at Ban Hua Thung community forest, $19^{\circ} 25^{\prime} 14^{\prime \prime} \mathrm{N}$, 98 $58^{\prime} 17^{\prime \prime}$ E, on unidentified decaying submerged wood, 5 August 2015, S. Sommai, FF00725.02 (BBH 40840, paratype) - living culture BCC79987 (TBRC 6544).

Notes - This fungus is best referred to the genus Parafuscosporella based on morphological characteristics (Yang et al. 2016). Our new species differs from the other Parafuscosporella species in having longer, wider and obpyramidal conidia, which are coronate at the apex with unusual conical projections. The molecular evidence (Fig. 1) also differentiates this taxon from the other species. 


\section{Discussion}

In phylogenetic analysis of in-group taxa and related fungal species from Sordariomycetes, $P$. garethii grouped in the order Fuscosporellales, sub-class Hypocreomycetidae and class Sordariomycetes (Boonyuen et al. 2011, Maharachchikumbura et al. 2015, 2016, Réblová et al. 2016, Yang et al. 2016). Parafuscosporella garethii clustered with the type species of the genus ( $P$. moniliformis). Morphologically, $P$. garethii can be differentiated from P. moniliformis by conidial shape and conidiophore size. Conidia of $P$. garethii $(37.5-47.5 \times 25-42.5 \mu \mathrm{m}$ diameter, 20-32.5 $\mu \mathrm{m}$ thick, 1-2-septate) are obpyramidal, coronate at the apex, with conical projections and longer than those of $P$. moniliformis (28-37 $\times 14-21 \mu \mathrm{m}$ diameter). In $P$. moniliformis, the conidiophores are mostly moniliform, lack a jelly-like sporodochial matrix, and have ellipsoidal to obyriform conidia, while those of our novel species and P. mucosa have a jelly-like sporodochial matrix. Phylogenetically, Parafuscosporella species group in a sister group to Fuscosporella pyriformis and Pituispora pseudosepta although they share similar morphological characteristics (Yang et al. 2016).

\section{Acknowledgements}

This paper was funded by grant from BIOTEC (infrastructure; P-14-51395). Janet Jenifer Luangsa-ard and Jariya Sakayaroj are specially thanked for their continual support for the study of fungal diversity. The staff at Ban Hua Thung, Chiang Mai Province, Thailand are thanked for allowing us to collect samples and providing the materials for this study. Last and most importantly, the first author would like to express deep gratitude to Prof. E.B. Gareth Jones as one of my mentors, and for his permission for the proposed name of the novel taxon.

\section{References}

Boonyuen N, Chuaseeharonnacha C, Suetrong S, Sri-Indrasutdh V et al. 2011 - Savoryellales (Hypocreomycetideae, Sordariomycetes): a novel lineage of aquatic ascomycetes inferred from multiple-gene phylogenies of the genera Ascotaiwania, Ascothailandia and Savoryella. Mycologia 103, 1351-1350.

Chuaseeharonnachai C, Somrithipol S, Boonyuen N. 2016 - Periconia notabilis sp. nov. and a new record and notes on the genus in Thailand. Mycotaxon 131, 491-502.

Hall T. 2004 - BioEdit. Ibis Therapeutics, Carlsbad, CA, 92008, USA. http://www.mbio.ncsu.edu/ BioEdit/bioedit.html.

Hernández-Restrepo M, Gené J, Castañeda-Ruiz RF, Mena-Portales J, Guarro J. 2015 Emendation of the genus Bactrodesmiastrum (Sordariomycetes) and description of Bactrodesmiastrum monilioides sp. nov. from plant debris in Spain. Mycological Progress 14, 48, doi:10.1007/s11557-015-1067-6.

Index Fungorum. 2016 - http://www.indexfungorum.org/Names/Names.asp. (Accessed on October 2016).

Jayasiri SC, Hyde KD, Ariyawansa HA, Bhat J, Buyck B et al. 2015 - The Faces of Fungi database: fungal names linked with morphology, phylogeny and human impacts. Fungal Diversity 74, 3-18.

Kornerup A, Wanscher JH. 1963 - Methuen Handbook of Color. London: Methuen \& Co. Ltd. 195 p.

Liu Y, Whelen S, Hall BD. 1999 - Phylogenetic relationships among ascomycetes: evidence from an RNA polymerase II subunit. Molecular Biology and Evolution 16, 1799-1808.

Maharachchikumbura SSN, Hyde KD, Jones EBG, McKenzie EHC et al. 2015 - Towards a natural classification and backbone tree for Sordariomycetes. Fungal Diversity 72, 199-301.

Maharachchikumbura SSN, Hyde KD, Jones EBG, McKenzie EHC et al. 2016 - Families of Sordariomycetes. Fungal Diversity 79, 1-317.

NCBI - 2016 - http://www.ncbi.nlm.nih.gov/nuccore org (accessed 24 June 2016). 
O'Donnell K, Cigelink E, Weber NS, Trappe JM. 1997 - Phylogenetic relationship among ascomycetous truffle and the true and false morels inferred from $18 \mathrm{~S}$ and $28 \mathrm{~S}$ ribosomal DNA sequence analysis. Mycologia 89, 48-65.

Page RDM. 1996 - Tree View: an application to display phylogenetic trees on personal computers. Computer Applications in the Biosciences 12, 357-358.

Réblová M, Seifert KA, Fournier J, Štěpánek VB. 2016 - Newly recognised lineages of perithecial ascomycetes: the new orders Conioscyphales and Pleurotheciales. Persoonia 37, 57-81.

Sakayaroj J. 2005 - Phylogenetic relationships of marine Ascomycota. Ph.D. Thesis, Prince of Songkla University, Thailand.

Swofford DL. 2002. PAUP*: Phylogenetic Analysis Using Parsimony (* and other methods) version 4b10. Sunderland, Massachusetts: Sinauer Associates.

Yang J, Maharachchikumbura SSN, Bhat DJ, Hyde KD et al. 2016 - Fuscosporellales, a new order of aquatic and terrestrial Hypocreomycetidae (Sordariomycetes). Cryptogamie Mycologie $37,449-475$.

White TJ, Bruns T, Lee S, Taylor JW 1990 - Amplification and direct sequencing of fungal ribosomal RNA genes for phylogenetics. In: PCR Protocols: A Guide to Methods and Applications (eds). Innis MA, Gelfand D H, Sninsky JJ, White TJ. Academic Press, Inc., New York, pp. 315-322. 